\title{
THOMAS HobBes: A PHILOSOPHER OF WAR OR PEACE?*
}

\author{
Delphine Thivet
}

\begin{abstract}
Along with Machiavelli, Hobbes is usually regarded as the pre-eminent representative of the 'power-politics' school of classical realism. He is frequently quoted for his pessimistic depiction of the state of nature that he so famously described as a brutal and anarchic arena in which each individual seeks his own advantage to the detriment of all other individuals, in a perpetual struggle for power. As reflective of this, political realism is sometimes even named the 'Hobbesian tradition'. Yet there is reason to question whether the standard characterization of realism as a form of moral scepticism which 'resists the application of morality to war' provides an accurate description of Hobbes's political philosophy. In this essay I examine Hobbes's conception of war, in order to show how, in some fundamental respects, it deviates from this 'realism'.
\end{abstract}

Along with Machiavelli, Hobbes is usually regarded as the pre-eminent representative of the 'power-politics' school of classical realism. He is frequently quoted for his pessimistic depiction of the state of nature that he so famously described as a brutal and anarchic arena in which each individual seeks his own advantage to the detriment of all other individuals, in a perpetual struggle for power. As reflective of this, political realism is sometimes even named the 'Hobbesian tradition'. ${ }^{1}$ Yet there is reason to question whether the standard characterization of realism as a form of moral scepticism which 'resists the application of morality to war', ${ }^{2}$ provides an accurate description of Hobbes's political philosophy. In this essay I examine Hobbes's conception of war, in order to show how, in some fundamental respects, it deviates from this 'realism'. Indeed, it is often overlooked that Hobbes in fact proposes a normative doctrine of war, even though this doctrine departs from the approach to war that was adopted by the main proponents of the Just War tradition, it can still be shown (and this will be the main burden of this essay) that Hobbes does not entirely refrain from placing moral restraints on the conduct of belligerents.

\section{Defining the 'State of War'}

No philosophy may be said to be entirely new, for each thinker inherits many influences from his predecessors. In this perspective, Hobbes's definition has close similarities with the one proposed by Grotius, even if these two thinkers are often said to belong to complete antithetic traditions. The reader may consider the definition of war that Hobbes proposes to the reader on Chapter XIII of Leviathan:

\footnotetext{
* This article was supported by the European Community's Human Potential Programme under contract HPRN-CT-2002-00231, 'Applied Global Justice'. I would like to thank Gregory Reichberg, Raino Malnes and Luc Foisneau, as well as an anonymous BJHP referee, for their valuable suggestions on earlier versions and for language improvements.
} 
WARRE (natura belli), consisteth not in Battell (non in pugna) onely, or the act of fighting; but in a tract of time (in tractu aliquo temporis), wherein the Will to contend by Battell is sufficiently known (quo durante voluntas armis decertandi est manifesta). ${ }^{3}$

First Hobbes does not specify the nature of the actors involved in war. This deficiency illustrates the non-relevance for him of the distinction between public wars led by sovereign powers and private wars, that is, duels engaged in by individuals. Hobbes's own definition therefore differs from the one proposed by Alberico Gentile, an early theoretician of the classical Just War tradition, who restricted war to public war. ${ }^{4}$ Yet like Grotius before him, Hobbes favored a broad concept of war because of 'its universal application to the armed conflicts in Europe' ${ }^{5}$. Onuma Yasuaki speaks in this respect of an 'all-inclusive' concept of war, which was well-suited to the political structure of seventeenth century, namely 'an extremely complicated political structure, a network of feudal relations, involving lords and vassals and a series of religious and political relations of alliance and hostility'. ${ }^{6}$

Hobbes by this definition does not prejudge the nature, just or unjust, of particular wars. His definition remains neutral concerning the justice or lawfulness of war. From this there follows an important consequence, namely, war in Hobbes's philosophy is not a strictly juridical concept. Hobbes's view of war is descriptive rather than normative, in line with his notion of a 'state of nature': War, for him, is first and foremost a de facto condition of human nature.

Secondly, it can be seen than Hobbes distinguishes war as a state from the actual acts of war such as battles. Here he inherits Grotius's definition of war as a 'status' [non actio, sed status. ${ }^{7}$ By this Grotius meant that war is 'a state which may exist even while its operations are not continued'. ${ }^{8}$ Hence war as a whole could be distinguished from its individual parts, so that a war could be considered ongoing even if fighting ceased for some time. In this vein, Hobbes described war as an 'allegorical monster' - a Behemoth, 'dozing for a tract of time, but without being dead for all that, preventing the angel of peace from being revived'. ${ }^{9}$ In chapter XIII of Leviathan, Hobbes uses a meteorological analogy to make his point:

Therefore the notion of Time, is to be considered in the nature of Warre; as it is in the nature of Weather. For as the nature of Foule weather, lyeth not in a showre or two of rain; but in an inclination thereto of many dayes together: So the nature of War, consisteth not in actuall fighting; but in the known disposition thereto, during all the time there is no assurance to the contrary. All other time is PEACE. ${ }^{10}$

Like weather, war refers to a stretch of time which is characterized by an inclination to certain acts that nevertheless do not necessarily occur continuously. In this respect it describes something akin to the Aristotelian condition of potentiality. For this reason, it would be anachronistic to interpret the Hobbesian notion of a 'state of war' as a juridical or normative condition, that is, a condition wherein adversaries are required to conduct hostilities within certain pre-determined limits. Rather it refers to a particular set of psychological predispositions, which are opposed to the attitudes which characterize the state of peace.

Furthermore, to understand what Hobbes means in his definition by 'the will [voluntas] to contend', we need to consider his doctrine of volition, particularly as it appears in Chapter VI of Leviathan. In contradistinction with 'vital motion'- a 
mechanical motion relating to behaviour from birth and '[continuing] without interruption through whole life'- Hobbes characterizes 'voluntary motion' as a dynamic, teleological motion, deriving from a conception of the future 'caused in us by external objects' and depending on the imagination, or on 'a precedent thought of whither, which way, and what'. ${ }^{11}$ Hobbes also distinguishes will (which always terminates in an act) from a mere inclination. An inclination is a tendency which one has always the liberty to follow or not. Will, by contrast, refers to the taking away of one's liberty: the deliberation has been achieved and one's last appetite or aversion produces a specific action, ${ }^{12}$ which in the case under consideration is a 'contention' or 'battle'. Thus, in Book I, Chapter XII, §7 of the Elements of Law (which deals precisely with the doctrine of volition), Hobbes writes that: 'When the wills of two divers men produce such actions as are reciprocally resistances one to the other, this is called CONTENTION: and being upon the persons of one another, BATTLE' ${ }^{13}$

On this understanding, the 'will to contend' refers in Hobbes' definition to a condition of 'reciprocal resistance' in which two or more individuals stand ready to do each other harm, due to a mutually recognized perception of their contrary interests. Hobbes emphasized this last point when he added the phrase 'by words or by actions', suggesting the existence of a semiotics of war. ${ }^{14}$ This important dimension of Hobbes's philosophy has often been neglected, even though John Locke took up Hobbes's formulation on this point: 'declaring by word or action, not a passionate and hasty, but sedate, settled design upon another man's life puts him in a state of war with him against whom he has declared such an intention'. ${ }^{15}$ Tacit (rather than overt) signs can also serve to initiate war, when one for instance demonstrates an arrogant superiority towards others which contradicts a human being's equality by nature. ${ }^{16}$ By contrast, Hobbes suggests that peace rests on what may be called peaceful semiotic codes. Thus, in On the Citizen, the avoidance of insolence is listed as one of the laws of nature (types of behaviour that promote peace). ${ }^{17}$

To sum up the various elements of Hobbes's definition of war, we see that Hobbes both inherits and distances himself from the Just War tradition: on one hand, he borrows from Grotius the idea that war is a 'state' which is distinct from individual acts of combat or battle. On another hand, he distances himself from any attempt to give to war a moral or juridical meaning, and focuses instead on describing its attitudinal and semiotic aspects.

\section{The causes of war}

The notion of 'causa belli' is far from being obvious: it may refer to the origin of war, but also and more subjectively to the reason or motives of the belligerents. One may consider therefore either what moves the belligerents (efficient cause), or the purpose or end of the war (final cause). As Peter Haggenmacher emphasizes, many scholastic authors and legists of the Just War tradition often confused material, final and efficient causes, ${ }^{18}$ embracing in one whole quite different issues such as the origin of a war, the matter in litigation, the identity and aim of the belligerents.

For Just War thinkers such as Gentile ${ }^{19}$ and Grotius ${ }^{20}$, the question of 'causa belli' specifically coincides with the normative issue of the justification of war. In this perspective, their inquiry focuses on the 'just causes' of war. Gentile for instance distinguishes the 'just causes' or 'legitimate reasons' for beginning the war from 'some plausible reason' usually alleged by princes, which he judges to be mere 'pretexts' for the lust for power. Similarly, in De jure belli ac pacis (II, Ch. I), Grotius 
distinguishes 'justifying causes' (causae iustificae) from merely persuasive cause (causae suasoria). ${ }^{21}$ The former relates to justice, the latter to mere utility. ${ }^{22}$ In most cases, belligerents have persuasive causes, but do not always have just causes. ${ }^{23}$ For Grotius asserts that here can be no other just cause for waging war than injury received'. ${ }^{24}$

At first sight and in contrast with Grotius's normative perspective, Hobbes sets aside the issue of just causes and rather focuses on the anthropological causes of war. Deliberately formulating his political theory along anthropological lines, Hobbes first provides an analysis of the causes of war based on the passions of human beings. For, the passions are conceived by Hobbes as 'the Interiour Beginnings of Voluntary Motions', ${ }^{25}$ and since he includes in his definition of war the notion of 'will' [voluntas], one can gather their importance for his conception of war. From a mechanistic point of view the passions are to be considered as efficient causes of men's actions, moving the mind and then the body. Thus, the 'will to contend', defining the condition of war, may be deduced from men's passions; and sometimes Hobbes explicitly describes war as 'an Inference, made from the Passions'. ${ }^{26}$

But paradoxically, Hobbes does not condemn the passions overall; on the contrary, several times he reiterated the view that the passions are not bad in themselves. ${ }^{27}$ Hobbes recognizes a fundamental distinction between passions that hinder the use of reason (perturbatio animi) and passions that are guided by reason. ${ }^{28}$ The former pursue a present good without foreseeing the greater evils that may proceed from it, whereas the latter are in accordance with the long-term goals reason provides to men, that is, self-preservation, avoidance of pain and injury, and the attainment of security and felicity. ${ }^{29} \mathrm{He}$ lists the passions 'of war' that contradict the ends defined by reason (i.e. are contrary to individual self-preservation); they are: 'desire of riches' (Covetousness), 'ambition', 'revengefulness', 'glory' and 'vainglory', 'laughter', 'cruelty', ' emulation' and 'envy'. ${ }^{30}$ All of these may be characterized by one dimension, that is, the vanity of their ends. 'Vanity' in Hobbes's vocabulary suggests unprofitable or useless ends. ${ }^{31}$ On this understanding, any passion, such as glory, 'beget[ing] no appetite nor endeavour to any further attempt, $[\ldots]$ is merely vain and unprofitable'. ${ }^{32}$ For example, revenge is said to be vain because it does not consider any future good, and hence the law of nature forbids $\mathrm{it}^{33}$.

Hobbes suggests rather looking at the final causes pursued by human beings in war. In the writings prior to Leviathan, the concept of natural right taken together with the idea of rationality provide a normative theory. ${ }^{34}$ Indeed, the definition of "right of nature' -understood as a right of self-preservation- ${ }^{35}$ includes an internal reference to right reason: 'What is not contrary to right reason, writes Hobbes, all agree is done justly and of Right. For precisely, what is meant by the term Right is the liberty each man has of using his natural faculties in accordance with right reason' ${ }^{36}$ Indeed right reason refers to a law Hobbes calls the 'Fundamental Law of Nature' - ' to seek peace when it can be had; when it cannot, to look for aid in war [auxilia belli]' - and that teaches men 'about what should be done or not done for the longest possible preservation of life and limb'. ${ }^{37}$

From this point of view only war undertaken for motives of self-preservation is fully legitimate according to Hobbes's theory. His originality, by contrast with Just War theories, lies in deriving the legitimacy of self-defence not from the 'injustice' of the aggressor, but simply from the principle of self-preservation. Self-defence is thus legitimate even against a 'just' aggressor. Furthermore, the 'unjust' aggressor, the 
thief, or the invader waging war or violating civil law for motives that do not deal with self-preservation, but rather out of 'vain glory' or ambition, cannot be blamed for resisting and using all means of self-defence possible against a 'just' counterattacker. ${ }^{38}$ One may conclude, therefore, that a normative theory of the causes of war is consistent with Hobbes's broader philosophy. This is clear in Chapter XIII of Leviathan where Hobbes distinguishes three principal causes of war: competition, diffidence, and glory. ${ }^{39}$ As we will see, Hobbes does not condemn the different kinds of war that may arise equally: indeed he asserts that men willing to do harm do it "not for the same reason or with equal culpability (non ab eadem causa, neque aeque culpanda) ${ }^{40}$

\section{Three kinds of war}

The first kind of war that may be discerned in Hobbes' political philosophy is 'war of necessity' or war over resources. 'War of necessity' is not an expression Hobbes himself used, but sums up war waged for economic subsistence or out of necessity that he describes in terms of 'the use of fire, water, free air, and place to live in, and to all things necessary for life' ${ }^{41}$ According to Hobbes it constitutes the most primitive kind of war one can find in the history of humankind, as for instance in the war between tribes, economic motives being the most common cause of war (frequentissima causa quare homines se mutuo laedere cupiunt).$^{42}$ Hobbes presents competition for scarce goods giving rise to war as caused by conditions such as overpopulation, which places individuals in direct competition for the satisfaction of their needs. War for necessity thus arises from an objective conflict of needs, where only the use of force can decide of the distribution of goods, acting as an arbitrator in the absence of a social institution able to solve the distribution problem:

The most frequent cause why men want to hurt each other arises when many want the same thing at the same time, without being able to enjoy it in common or to divide it. The consequence is that it must go to the stronger. But who is the stronger? Fighting must decide (pugna judicandum est). ${ }^{43}$

For Hobbes, war of necessity represents a 'rational' kind of war, needs being always 'excused' as motives in accordance with individual's 'natural rights':

When a man is destitute of food, or other thing necessary for his life, and cannot preserve himselfe any other way, but by some fact against the Law; as if in a great famine he take the food by force, or stealth, which he cannot obtaine for mony nor charity; or in defence of his life, snatch away another mans Sword, he is totally Excused, for the reason next before alleged. ${ }^{44}$

If the use of force, out of vital necessity or for reasons of 'economic subsistence' seems a rational and acceptable motive at the individual level, it is another matter whether it also applies to the case of states. So, for instance, does a state, lacking of the necessary means of subsistence, water, food, for its citizens suffering famine, have the right to attack another state which has these resources, even if not in abundance? Since the goods of land and sea are not equally divided in all territories, and because of geographical disparities (the nature of soils, climates, etc.), states search for the necessities for subsistence from foreign places, pacifically by trade and importation, but also by war. And Hobbes believes justly, with the proviso that a state may refuse to share, or forbid the free exchange of, necessary resources: 
[B]ecause there is no Territory under the Dominion of one Common-wealth, (except it be of very vast extent,) that produceth all things needful for the maintenance, and motion of the whole Body; and few that produce not something more than necessary; the superfluous commodities to be had within, become no more superfluous, but supply these wants at home, by importation of that which may be had abroad, either by Exchange, or by just Warre, or by Labour. ${ }^{45}$

Was Hobbes by this statement trying to provide a theoretical justification for competition over natural resources? This at least the interpretation of Richard Tuck who considers that Hobbes's theory of war of necessity as leading to the justification of colonization. Paradoxically, while he was a member of two English colonial trade companies - as Noel Malcom has established- ${ }^{46}$ Hobbes seems not to have directly taken part in the debate over the conquest of the New World. No theoretical justification of European's economic activities or of the Spanish conquest can be found explicit in his writings.

It is of course difficult to interpret this silence and to speculate what Hobbes might have thought about it. But a specific and sharp debate in England at the time about the Norman Conquest gives some indication of the theoretical issues at stake for Hobbes on the issue of conquest, especially the questions of consent to and legitimacy of the new political entity. ${ }^{47}$ It follows that colonization has to be distinguished in Hobbes's political theory from conquest: ${ }^{48}$ the former being understood as the acquisition of rights over land, like the practice of planting settlement, and involving a theory of the right of 'propriety' or of appropriation; ${ }^{49}$ the latter meaning the transfer of political obedience from the vanquished to the victor. Actually, Hobbes does distinguish conquest from the exploitation of territories and superfluous resources. In the case of poverty, he considers that use of force may be legitimate not only to get vital resources but also to occupy unoccupied or uncultivated lands, so as to use them, cultivate soils, etc., which could be read in his time as condoning the institution of the first plantations in the New World, especially in North America: ${ }^{50}$

The multitude of poor, and yet strong people still encreasing, they are to be transplanted into Countries not sufficiently inhabited: where, neverthelesse, they are not to exterminate those they find here; but constrain them to inhabit closer together, and not to range a great deal of ground, to snatch what they find; but to court each little Plot with art and labour, to give them their sustenance in due season..$^{51}$

What sort of remedies for 'war of necessity' does Hobbes have in mind then? According to his theory, the general means to prevent this kind of war lies in the twelfth law of nature, which advocates equal use of things in common: 'That such things as cannot be divided, be enjoyed in Common, if it can be; and if the quantity of the thing permit, without Stint; otherwise Proportionably to the number of them that have Right' ${ }^{52}$ But, it is at the civil level, more specifically, that the natural needs of men can be fulfilled and peace established by an appropriate economic organization that goes beyond natural needs, furnishing 'all the comforts and amenities of life which peace and society afford' ${ }^{53}$ It is in this sense that Gregory Kavka talks about a minimal 'economic welfare state' in Hobbes's theory. ${ }^{54}$ For he sees it as the duty of the sovereign to ensure the safety of his subjects, 'not mere survival in any condition, but a happy life (vita beata) so far as that is possible' ${ }^{55}$. As for the level of 
international relations, there Hobbes, like Francis Bacon, ${ }^{56}$ advocated free trade as a way of fostering peace: ${ }^{57}$

It is also a law of nature, That men allow commerce and traffic indifferently to one another. For he that alloweth that to one man, which he denieth to another, declareth his hatred to him, to whom he denieth; and to declare hatred is war. And upon this title was grounded the great war between the Athenians and the Peloponnesians. For would the Athenians have condescended to suffer the Megareans, their neighbours, to traffic in their ports and markets, that war had not begun. $^{58}$

If Hobbes diagnoses the first kind of war as 'war of necessity', the second kind is 'preventive war' which results from 'diffidence'. ${ }^{59}$ One may define it as a war waged against a potential aggressor before any actual attack from the latter. With his concept of 'preventive war', Hobbes distances himself from the Just War Tradition by attempting to define a war of aggression - under particular conditions that I will specify- as a kind of defensive war. As we shall see, definition of the appropriate moral conditions for self-defence rest for Hobbes not only on the objective and effective attack, but also on the subjective belief of insecurity on the part of agents, namely, on their fear. Hobbes with this original perspective comes up against the limits of his own normative theory, noting the impossibility of ruling out general principles regarding an individual's self-preservation.

As we have seen above, Hobbes deduced from the right of nature that each time one judges that his/her self-preservation is being threatened, one is allowed to defend him/herself, by every means he/she judges the most appropriate. In the condition of mere nature, writes Hobbes in Chapter XIV of Leviathan, 'all men are equall, and judges of the justnesse of their own fears' ${ }^{60}$ Even in the civil state, individuals never entirely give up their 'right of nature'. But as Howard Warrender has demonstrated, there is an important distinction between the state of nature /international relations, and the civil state measured in terms of the 'objectivity' of the state of 'insecurity'. ${ }^{61}$ Grotius's objection to Gentile's conception of 'balance of power' is well known: it states in particular the absurdity of resting the justness of war on a supposed lack of 'insecurity'. For, as Grotius reminds us, 'such ... is the condition of human life, that full security cannot be enjoyed'. ${ }^{62}$ In the state of nature and by analogy in international relations, because of the absence of a sovereign- one can find an objective situation 'where an Invader hath no more to feare, than an other mans single power', ${ }^{63}$ which makes ambitious men generally safe from any punishment for their aggressions. Inevitably, it leads to a state wherein the expectation of effective attacks is more likely. This expectation gives birth to 'diffidence' (metus), in Hobbesian terminology 'mistrust', a feeling that leads a man to actions that Hobbes considers fully reasonable and justified, namely, 'Anticipation', 'that is, by force, or wiles, to master the persons of all men he can, so long, till he see no other power great enough to endanger him. ${ }^{64}$

The definition of threat or danger lies at the heart of the debate. As we have noted, Hobbes denies any 'absolute' definition of danger. Does this mean that, according to him, fear in itself constitutes a sufficient (that is, reasonable) motive to wage war? In fact, it is necessary to distinguish between a 'reasonable suspition' and an irrational fear. ${ }^{65}$ Gentile himself, although he advocates preventive war, asserts that fear should always have a 'just cause' to be legitimate, asserting that preventive war 
'does not apply, (as Euripides says), to cases when one fears without reason. For who is there who can prevent a man from being afraid of his own shadow?' ${ }^{\prime 6}$. Hobbes ranks fear among the possible excuses or extenuating circumstances in committing a crime, but he specifies:

$[\mathrm{N}]$ ot every Fear justifies the Action it produceth, but the fear onely of a corporeall hurt, which we call Bodily Fear, and from which a man cannot see how to be delivered, but by the action. [...] to kill a man, because from his actions, or his threatenings, I may argue he will kill me when he can, (seeing I have time, and means to demand protection, from the Soveraign power,) is a Crime. ${ }^{67}$

Citizens living under the protection of the sovereign - except in extreme circumstances where the sovereign fails in his function of protecting the individual's life - cannot be excused in waging a preventive war, even if civil society is not an 'absolute' state of security - which in any event does not exist in Hobbes's theory - it is enough the individuals enjoy a 'sufficient Security'. ${ }^{68}$ In comparison, outside civil society, in the absence of any kind of 'international' contract and sovereign, one can conclude that, from an 'Hobbesian' point of view, states can legitimately distrust each other's intentions, and plead for self-defence against insecurity or some hypothetical threat.

Hobbes's conception of self-defence led us to investigate the circumstances in which preventive war is or is not, according to him, justifiable. On the one hand, Hobbes asks to consider the objective situation of probable insecurity created by the absence of political institutions, especially at the level of international relations; on the other, he stresses the subjective nature of the estimation of individual's safety, as well as the State's preservation. Finally, Hobbes at the same time appears to justify preventive war, providing us with the limits of a 'just' appreciation of what can be conceived as a 'sufficient threat', and questioning the possibility of irrational fear but also of abuses based on Machiavellian interests rather than on self-preservation.

Ambition, quest for power or vain-glory represent the last causus belli that Hobbes examines. According to him, as we shall see, it represents the worst kind of war as a type of 'unjust' war. Hobbes's condemnation of war concerns mainly the third kind of war which he terms 'vain' because it springs from the passion, 'vain glory': 'Of the Passions that most frequently are the causes of Crime, one, is VainGlory, or a foolish over-rating of their own worth'. 'Vain war' means literally a war waged vainly, that is a war that is not based on any more serious reason than the 'flattery of others' and the 'supposing of power'; 69 a kind of war, Hobbes writes, waged, 'for [such] trifles, as a word, a smile, a different opinion, and any other signe of undervalue, either direct in their Persons, or by reflexion in their Kindred, their Friends, their Nation, their Profession, or their Name'. ${ }^{70}$

Glory, linked to the question of ego and honour peculiar to an aristocratic society, rests on comparison, and then competition between the individuals, wherein every one wants to be judged by the others as superior, struggling to maintain his social reputation. What is at stake is not self-preservation as such. Rather men are ready to wage war and to take the risk of violent death for reputation and honour on the model of 'duel', ${ }^{71}$ so common in the seventeenth century, for the sake of 'signs of power' or 'opinion of power', ${ }^{72}$ that is, social recognition.

Hobbes excoriates the irrationality of 'vain war' describing, in several extracts of his works, the specific dispositions, namely a kind of intemperance, that make 
human beings 'tak[e] pleasure in contemplating their own power in the acts of conquest, which they pursue farther than their security requires' ${ }^{73}$

So Hobbes makes a clear distinction between rational motives to go to war and wars waged on irrational grounds, that is, 'vain' wars. For him the only (morally) justifiable causes of war derive from the primary right of self-preservation: namely, scarcity of goods and defence from aggression. In the latter cases states prepare their defences lawfully, establishing 'the obedience and unity of the subjects', gathering 'the means of levying soldiers', 'having money, arms, ships, and fortified places'; ${ }^{74}$ while, at the same time, Hobbes acknowledges that good defence lies 'in the avoiding of unnecessary wars'.75 Indeed, any other motive for waging war than selfpreservation appears in some way 'unjust', or more precisely "irrational", that is, contrary to 'right reason' which, as C.A..J Coady points out, 'introduces a positive, normative element into the definition of right' ${ }^{76}$

Nonetheless, some limitations of Hobbes's theory must be noted. First and foremost, as his theory of 'preventive war' well demonstrated, his notion of 'right reason' lacks objectivity: it is purposefully defined as a subjective faculty. In the state of nature each man's own reason is regarded as the measure of his actions. As long as an individual or a state judges that they legitimately exercise their natural right of selfpreservation when waging war, therefore, it is said that they are acting 'by right' and may be considered 'blameless', without however - and this makes a difference in the Just War tradition - creating any correlative obligation on the part of others. Indeed, among the justifiable causes of war, Hobbes never takes into account the injustice of the aggressor. Any theory that sees war as punishment for the violation of rights or injury received, as theorized for instance in Grotius's De Jure Belli ac Pacis, ${ }^{77}$ is totally absent from Hobbes's theory. Does Hobbes therefore deserve to be portrayed as a sceptical realist?

\section{The conduct of war}

It seems, when Hobbes quotes Cicero that 'Laws remain silent in the midst of arms'(inter arma silent leges)', that one may answer positively. ${ }^{78}$ As I shall try to show, in the absence of a coercive power, war appears to Hobbes to be a condition of absolute independence where individuals in the state of nature, or states at the level of international relations, are not bound to each other, that is, do not have any legal obligations or duties, but only a 'right to all things'. For 'As long as a person has no guarantee of security from attack, his primeval Right remains in force to look out for himself in whatever ways he will and can, i.e. a Right to all things, or a Right of war' ${ }^{79}$ In the state of war the right of all men to all things (jus omnium in omnia) therefore involves that 'one man rightly attacks (alter jure invadit) and the other rightly resists (alter jure resistit)'. Right does not belong to one side rather than the other. In fact, with this characterization of jus belli Hobbes may be seen as anticipating one important dimension of the modern notion of jus in bello: namely, equality between the belligerents, irrespective of the justice or injustice of their cause. In stressing the equal right of nature of each opponent in war, in comparison to Just War tradition, Hobbes gives up the Just War theory's distinction between the 'just' combatant and the 'unjust' one, because all combatants are at equal and blameless liberty to defend themselves. The tension particular to Just War theory between the just cause (jus ad bellum or 'justice in going to war') and the conduct of war (jus in bello or 'justice in the conduct of war') - thus disappears. 
Being careful to avoid anachronism, given that the modern sense of jus in bello establishing equality between all belligerents and the bilateral laws of war, ${ }^{80}$ differs from the classical conception and was not available in the seventeenth century, we may ask ourselves about the process which later in the eighteenth century, led, with such international lawyers as Wolff, De Vattel or Martens, to the regulation of the conduct of war for both belligerents, irrespective of the cause of war. Paradoxically then, Hobbes's political philosophy may be thought of as both a turning-point and a point of reference for the revaluation of jus in bello, independent of jus ad bellum, that is, without consideration of the nature, whether just or unjust, of the belligerents, but only with respect to their equality. Furthermore, Hobbes asserts that natural equality provides the belligerent with an unlimited right of war, that is, the liberty to defend himself 'in whatever ways he will and can'.

Does this mean that for Hobbes everything is permissible in war? Does Hobbes conceive of any laws of war? If not, does he not at least recognise some kind of limitation on the right of war (jus belli)? The proverbial saying 'inter arma silent leges' suggests an extreme realist point of view on the conduct of war. Bearing in mind Hobbes's conception of justice, one may indeed be sceptical about the relevance of the notion of jus in bello to his political philosophy. For Hobbes's theory of justice gives precedence to a contractual conception of justice, consisting in the keeping covenants, over the moral sense of justice, as a virtue. ${ }^{81}$ Hobbes, like Grotius, criticises the classical conceptual distinction between commutative and distributive justice, inherited from Aristotle. But by contrast with Grotius, he inherits in addition the voluntarism and nominalism of William of Ockham: which underpins his legal positivism and thus his separation of civil law from morality. Hobbes identifies the justice of actions with commutative justice, that is, justice based on a former covenant.

Hobbes adds a second and necessary condition to the definition of justice, and one that has contributed to his reputation as a 'legal positivist': it concerns the conditions under which men are able effectively to perform their covenants. Aware of the limits of trust between human beings, the English philosopher stresses the general weakness of words by themselves (the Epicurean flatus vocis or 'vain' words). Hobbes finds in fear of punishment, or more precisely, in the passion of 'terror', an efficient way of leading men to perform their covenants. This fear obtains in two different kingdoms: God's kingdom, which means the fear of a divine punishment; and the earthly kingdom, incurring therefore a human punishment. ${ }^{82}$ The fear of human punishment is a reflex of the power of a civil sovereign to force individuals to implement their covenants, so that where no such civil power is instituted - as at the international level or in paradigmatic cases of state of nature- the only fear that can lead men to perform their covenants is fear of divine punishment:

[B] efore the time of Civill Society, or in the interruption thereof by Warre, there is nothing can strengthen a Covenant of Peace agreed on, against the temptations of Avarice, Ambition, Lust, or other strong desire, but the feare of that Invisible Power, which they every one Worship as God; and Feare as a Revenger of their Perfidy. ${ }^{83}$

Where no civil sovereign is instituted justice still reduces itself to a moral law ${ }^{84}$ or, possibly, to a divine law ${ }^{85}$ but with the difference that there is no civil sanction and divine sanction deals only with individual consciousness. For Hobbes the primary sense of Law is civil law, that is, law of civil institution endowed with the 
power of coercion. This means that juridical obligations are restricted to obligations backed up by coercion. ${ }^{86}$ By the specific kind of fear it inspires the state guarantees that covenants will be performed and so gives meaning to the terms 'just' and 'unjust':

Therefore before the names of Just, and Unjust can have place, there must be some coercive Power, to compell men equally to the performance of their Covenants, by the terrour of some punishment, greater than the benefit they expect by the breach of their Covenant. ${ }^{87}$

At the level of international relations, given that the institution of an international sovereign is lacking, Hobbes cannot conceive any jus in bello in a juridical or legal sense, that is, the institution of legal obligations in the state of war:

The notions of Right and Wrong, Justice and Injustice have there no place. Where there is no common Power, there is no Law: where no Law, no Injustice. Force, and Fraud, are in warre the two Cardinall vertues. ${ }^{88}$

This is Hobbes's so-called 'classical realism': the international system in which coercive human laws binding sovereign states are lacking remains as realm of absolute license. In this respect the more general notion of jus gentium, which comprises the jus in bello and is defined as the forerunner of international law, that is, a set of legal rules or a juridical system applicable to sovereign states, seems irrelevant to Hobbes's philosophy. Does it mean that Hobbes rejects the notion of jus gentium outright? As we shall see, Hobbes is logical in identifying the notion of jus gentium with the laws of nature as defined in the state of nature, that is to say, as moral rules.

As a French jurist notices, ${ }^{89}$ most of the actual research on jurisprudence has focused on natural right, disregarding an other important part of the natural law school's doctrine, that is, the notion of jus gentium (defined as the law which should prevail between sovereign states). The same goes apparently for Hobbes's political philosophy. Yet, paradoxically, Emer de Vattel who has devoted a book to the notion of 'Laws of Nations'- and who talks about the 'detestable principles [of Hobbes]'nevertheless acknowledges the English philosopher as 'the first [who gave] us a distinct though imperfect idea of the Laws of Nations'. ${ }^{90}$ We shall examine where Hobbes precisely stands in this respect.

Consistent with his own conception of right, Hobbes first begins by picking out unsuitable features of the expression 'jus gentium' - those that imply moral obligations at the international level:

Natural law can again be divided into the natural law of men (naturalem hominum), which alone has come to be called the law of nature (lex naturae), and the natural law of commonwealths (naturalem civitatum), which may be spoken of as the laws of nations [lex gentium], but which is commonly called the right of nations [ius gentium]. The precepts of both are the same: but because commonwealths once instituted take on the personal qualities of men, what we call a natural law in speaking of the duties of individual men is called the right of Nations (jus gentium), when applied to whole commonwealths, peoples, or nations. And the Elements of natural law and natural right (legis et juris naturalis) which we have been teaching may, when transferred to whole commonwealths (civitates) and nations (gentes), be regarded as Elements of the laws and of the right of Nations (legum et juris gentium elementis). ${ }^{91}$

In this extract, Hobbes identifies the notion of jus gentium with natural law, merely noting that it designates a higher level of application of natural laws, that is to say, on the international level. Hobbes here clearly manifests a wish to distinguish jus 
gentium from the equivalent for states of the individual right of nature, that he sometimes refers to as a 'right of war' (jus belli). According to his definition of 'right'- sovereigns have indeed the same absolute 'liberty' 'that any particular man can have, in procuring the safety of his own Body'. ${ }^{92}$ The end of the quotation illustrates quite well that Hobbes has in mind this specific distinction: he opposes any attempt to make laws of nations equivalent to laws of nature on the interstate level, or in the form of a right of nations, equivalent to the individual right of nature or right of selfpreservation. So, the law of nature applied to the international level- what it is commonly but improperly called 'jus gentium' according to Hobbes's definition of 'right' - is renamed by him 'lex gentium'; while the phrase 'jus gentium' comes to signify more properly the contrary of what is thought of in the common meaning. However, Hobbes still remains confusing, due to the fact that he sometimes uses the phrase 'jus gentium' in the most common meaning of law of nations.

Far from merely a terminological change, this usage has important consequences for Hobbes's political theory. It suggests first that Hobbes does not acknowledge any juridical restraints in war - this is why he only conceives a Right of war. However, it does not mean that Hobbes denies any particular restrictions on this right, derived - as we shall see- either from custom, law of honour, or some form of law of nature between sovereign states. At the same time Hobbes tacitly refuses to consider jus gentium as a 'law' in the proper sense of the term as he defined it, that is, as a positive law binding on commonwealths in their mutual relationships, due to the absence of coercion. In a condition of independency, sovereign states remain the only judges of the best ways to protect their interests, having only laws of nature as rational guiding principles for their actions:

[T] he same Law, that dictateth to men that have no Civil Government, what they ought to do, and what to avoyd in regard of one another, dictateth the same to Commonwealths, that is, to the Consciences of Soveraign Princes, and Soveraign Assemblies; there being no Court of Naturall Justice, but in the Conscience onely; where not Man, but God raigneth; whose Lawes, (such of them as oblige all Mankind,) in respect of God, as he is the Author of Nature, are Naturall; and in respect of the same God, as he is King of the Kings, are Lawes. ${ }^{93}$

Hobbes's identification of jus gentium with the laws of nature differs from Grotius who shares on one side the same view ${ }^{94}$ but, on another side, admits customary and volitional foundations for jus gentium. ${ }^{95}$ On this point, the hesitations or ambivalence of Grotius's notion of 'jus gentium' - hesitations concerning the relationship between natural law, custom, and tacit consent between nations, giving to it a hybrid status- are radically rejected by Hobbes who refuses to conceive of any other source for positive law and obligation than the command of a sovereign. Furthermore, he probably thinks that a kind of 'volitional' law of nations does not suffice to set out universal law, as he considers this particular conception of jus gentium, as a kind of 'jurisprudence', based mainly on experience, history and will of various but not all nations. He himself refers to international customs ruling the behaviour of the states in war, but remaining for him a mere matter of facts, not a true dictate of right reason. At the international level it means that, as in the state of nature, Hobbes asserts the primacy of the right of war: 'Where there is no common Power, there is no Law: where no Law, no Injustice. Forces, and Fraud, are in warre the two Cardinal vertues'. ${ }^{96}$ Nevertheless, Hobbes acknowledges that in a state of war some laws of nature may oblige not only in intention, but also in act, such as the law of 
nature forbidding cruelty. In a note in the second edition of On the Citizen, Hobbes writes: 'There are some natural laws whose observance does not cease even in war. For I cannot see [...] cruelty (crudelitas) (which is vengeance without regard to future good) contributes to any man's peace or preservation'. ${ }^{97}$ So, despite his denial of the existence of any positive law of nations and the primacy of right of self-preservation with respect to the law of nature, Hobbes's political works modestly make room for some restrictions in the conduct of war. The following reference to an inter-state custom for instance, moderates the assertion that the right of war is beyond constraints:

Laws are silent among arms.[...] such is the state of nature, though in wars between nations a degree of restraint has normally been observed. ${ }^{98}$

[Q]uanquam in bello nationis contra nationem modus quidam custodiri solebat. ${ }^{99}$ Hobbes has no intention of instituting an international 'Leviathan' or sovereign, but he could be construed as admitting 'laws of war', that is coercive obligations with respect to the conduct of war in cases where state sovereigns are prepared to make covenants between them so as not to wage war without limits. One may object to pessimistic interpretations of Hobbes's theory that provided states agree to make covenants so as to establish some rules in the conduct of war, he thereby recognizes the possibility of a jus in bello, as tending to suggest that he acknowledges - as quoted- some limits in inter-states war. Indeed, the Latin word 'modus' has the connotation of 'moderation', or rule-following, the self-imposition of restraints. But 'moderating' behaviour is quite different from law-governed behaviour. Customs and treaties do not represent for Hobbes a legitimate source of law. As we have already suggested, they do not provide eternal and universal principles of right reason ${ }^{100}$ but rest only on temporal and limited agreements. Moreover, they lack the power of enforcement. A mutual agreement appears insufficient to regulate states' actions, for the sovereign power to ensure compliance is lacking. Rather than talking about 'laws of war', it would therefore seem more relevant and appropriate to refer, as Richard Cox has done about Locke's conception of war, to 'limitations on the right of war' 101 in Hobbes's political theory. The first limitation of the right of war, asserted in accordance with right reason, is to the effect that any acts in war that go beyond what one believes to be necessary for one's preservation violate the fundamental law of nature that commands men to seek peace.

[T] he law of nature commandeth in war: that men satiate not the cruelty of their present passions, whereby in their own conscience they foresee no benefit to come. For that betrayeth not a necessity, but a disposition of the mind to war, which is against the law of nature. ${ }^{102}$

Among these limitations are prohibitions against cruelty and respect for the law of 'honour'. A man who engages in war with cruelty can be judged as a weak and timorous man, and of a dishonourable attitude:

[A]11 men in whom the passion of courage or magnanimity have been predominant, have abstained from cruelty; insomuch that though there be in war no law the breach whereof is injury, yet there are those laws, the breach whereof is dishonour. In one word, the only law of actions in war is honour; and the right of war providence. ${ }^{103}$

By 'Honour', Hobbes refers to an aristocratic virtue in accordance with the strict code of the rules of duelling. Honour is also required by law of nature, ${ }^{104}$ and human beings always remain bound in foro interno by that fundamental law of nature, 
to 'seek peace'; an obligation that unfortunately remains unilateral and obtains only so long as there is sufficient security to fulfil it:

He that having sufficient Security, that others shall observe the same laws towards him; observes them not himselfe, seeketh not Peace, but War; \& consequently the destruction of his Nature by Violence. ${ }^{105}$

Hobbes's definition of justice acknowledges the possibility of covenants or the mutual transfer of rights between sovereign states at the international level, in the case, for example, of treaties or alliances. Nevertheless, covenants are not sufficient in themselves to define a jus in bello in the juridical and legal sense: indeed, in the absence of any coercive mechanisms to ensure men's fear of punishment, nothing can ensure states will respect their covenants. It appears therefore that in the absence of sovereign power the only notion of justice Hobbes accepts as regulating international relations is in the form of moral law, or laws of nature, a type of justice he calls 'justice of manners'. It is the same moral virtue obliging men towards God, a disposition men may have in foro interno to conform to reason.

\section{CONCLUSION}

The purpose of this essay was to present an overview of Hobbes's conception of war, not so much to stress again his pessimistic depiction of the state of nature and international relations, but rather to shed light on the neglected possible rationalist or 'unrealist' ${ }^{106}$ aspects of Hobbes's political philosophy. My concern was to investigate Hobbes's concept of war, and through this examination to query its relationship both to realist doctrine and to 'just war' doctrines so as to judge to what extent Hobbes's political philosophy distances itself from any normative tradition. In emphasising the role of power and self-interest in war and politics Hobbes may certainly be characterized as a 'realist', but my intention is to qualify this assertion by showing that he did not disclaim the role of moral principles in war; in fact we have seen that Hobbes admits some limitations in the conduct of war and excludes for instance cruelty and vain revenge, believing that only fear could justify the taking of life. It appears obvious also in his examination of the motives to go to war, and his condemnation of war waged for glory that his aim was 'at a minimum, [to eliminate] all but defensive wars', ${ }^{107}$ or as he writes, 'the avoiding of unnecessary wars'. ${ }^{108}$

Finally, the primary reference Hobbes makes to war, as 'one who has a passion for peace', 109 should not mislead us about the main purpose of his political philosophy. His writings continue to offer relevant and useful theoretical tools to those who would wish to reflect on the moral and political conditions for achieving a lasting peace. 


\section{REFERENCES}

${ }^{1}$ Raino Malnes, The Hobbesian Theory of International Conflict (Oslo: Scandinavian University Press, 1993), p.13.

${ }^{2}$ A.J. Coates, The Ethics of War, (New York: Manchester University Press, 1997), p. 17.

3 Thomas Hobbes, Leviathan, A Critical Edition by G.A.J. Rogers and Karl Schuhmann (Bristol: Thoemmes Continuum, 2003), vol. 2, p. 101; Id., Leviathan sive De Materia, Forma, et Potestate Civitatis Ecclesiastica et Civilis. Thomas Hobbes Malmesburiensis Opera Philosophica Quae Latine Scripsit Omnia In Unum Corpus Nunc Primum Collecta (London: Scientia Verlag Aalen, John Bohn, 1839-1845, reimprinted Aalen, 1966), vol. III, p. 99.

${ }^{4}$ Alberico Gentile, De Iure Bell Libri tres, translation of the edition of 1612, by John C. Rolfe, ( Oxford: Clarendon Press, 1933, reimprinted 1995), vol. 2, I, Ch. II , p. 12.

${ }^{5}$ Onuma Yasuaki, in Id. (ed.), A Normative Approach to war. Peace, War, and Justice in Hugo Grotius. (Oxford: Clarendon Press Oxford, 1993), p. 61.

${ }^{6}$ Ibid.

${ }^{7}$ Hugo Grotius, De Jure Belli ac Pacis Libri Tres, in quibus Jus Naturae et Gentium, item Juris Publici praecipua explicantur, ed. by James Brown Scott (Buffalo, New York : The Classics of International Law, 1995) I, Ch. I, § 2, p. 1.

${ }^{8}$ Ibid [III, Ch. XXI, § 1], p. 592; translated by me.

${ }^{9}$ Peter Haggenmacher, Grotius et la doctrine de la guerre juste (Paris : Presses Universitaires de France, 1983), pp. 459-460; my translation.

${ }^{10}$ Hobbes, Leviathan, pp. 101-102.

${ }^{11}$ Ibid., p. 42.

${ }^{12}$ Ibid., p. 50.

${ }^{13}$ Thomas Hobbes, The Elements of Law Natural and Politic, ed. by Ferdinand Tönnies, $2^{\text {nd }}$ ed. with a new Introduction by M.M. Goldsmith (London: Frank Cass \& Co., first ed. 1889, $2^{\text {nd }}$ ed.1969), p. 63.

${ }^{14}$ See Yves Charles Zarka, Ch. VI, « De la guerre », in Hobbes et la pensée politique moderne (Paris, Presses Universitaires de France, 1995).

${ }^{15}$ John Locke, Two Treatises of Government, ed. by P. Laslett (Cambridge: Cambridge University Press, 1992), Ch. III, § 16, p. 278. 
${ }^{16}$ See the comparison between the "modest men" and the "aggressive men" in Thomas Hobbes, On the Citizen, translated by R. Tuck and M. Silverthorne (Cambridge: Cambridge University Press, 1998), 1647 $2^{\text {nd }}$ ed., I, Ch.I, $\S 4$, p. 26.

${ }^{17}$ Ibid., I, Ch.III, § 12, p. 49.

${ }^{18}$ Haggenmacher, Grotius et la doctrine de la guerre juste, p. 153.

${ }^{19}$ Gentile, De Iure Bell Libri tres, I, Ch. VII, pp. 34 ff.

${ }^{20}$ Grotius, De Jure Belli ac Pacis Libri Tres, II, Ch. I, § 1 ff, pp. $100 \mathrm{ff}$.

${ }^{21}$ Ibid., p. 100.

${ }^{22}$ Ibid., II, Ch. XXII, pp. 384 ff.

${ }^{23}$ Ibid., II, Ch. XXII, § 3, p. 385.

${ }^{24}$ Ibid., II, Chapter I, § 1, p. 101.

${ }^{25}$ Hobbes, Leviathan, I, Ch. VI, p. 42.

${ }^{26}$ Ibid., I, Ch. XIII, p. 101.

${ }^{27}$ Hobbes, On the Citizen, Preface, p. 11; Leviathan, I, Ch. XIII, p. 101.

${ }^{28}$ Thomas Hobbes, De Homine. Elementorum Philosophice Sectio Secunda, De Homine. Thomas Hobbes Malmesburiensis Opera Philosophica Quae Latine Scripsit Omnia In Unum Corpus Nunc Primum Collecta (London: Scientia Verlag Aalen, John Bohn, 1839-1845, reimprinted Aalen, 1966), vol. II, Ch. XII, p. 104.

${ }^{29}$ B. Gert, 'Hobbes's account of reason and passion', in M. Bertman and M. Malherbe (ed.), Thomas Hobbes, de la métaphysique à la politique (Paris: Actes du Colloque Franco-américain de Nantes, 1989), p. 90 .

${ }^{30}$ Hobbes, Leviathan, I, Ch. VI, pp. $46 \mathrm{ff}$.

${ }^{31}$ Hobbes, The Elements of Law, I, Ch. VII, § 6, p. 30.

${ }^{32}$ Ibid., I, Ch. IX, § 1, p. 37.

${ }^{33}$ Ibid., I, Ch. XVI, § 10, p. 86.

${ }^{34}$ See C.A.J. Coady, 'The peculiarity of Hobbes's concept of natural right', in C. Walton and P.J. Johnson (ed.), Hobbes's 'science of natural justice' (Martinus Nijhoff Publishers, 1987), pp. 165-179.

${ }^{35}$ Hobbes, The Elements of Law, I, Ch. XIV, § 6, p. 71.

${ }^{36}$ Hobbes, On the Citizen, I, Ch. I, § 7, p. 27; I underline. 
${ }^{37}$ Ibid., I, Ch. II, § 2; § 1, p. 34; p. 33.

${ }^{38}$ See Hobbes, Leviathan, Ch. XXI, p. 174: '[even rebels who have unjustly resisted to the sovereign have the liberty to defend themselves] for they but defend their lives, which the guilty man may as well do, as the innocent. There was indeed injustice in the first breach of their duty; their bearing of arms subsequent to it, though it be to maintain what they have done, is no new unjust act'. I underline.

${ }^{39}$ Hobbes, Leviathan, p. 101.

${ }^{40}$ Hobbes, On the Citizen, I, Ch. I, § 4, p. 26.

${ }^{41}$ Hobbes, The Elements of Law, I, Ch. XVII, § 2, p. 88.

${ }^{42}$ Hobbes, On the Citizen, I, Ch. I, VI, p. 162.

${ }^{43}$ Ibid., p. 27.

${ }^{44}$ Hobbes, Leviathan, I, Ch. XXVII, p. 238.

${ }^{45}$ Ibid., I, Ch. XXIV, pp. 195-196.

${ }^{46}$ Noel Malcom, 'Hobbes, Sandys and the Virginia Company', Historical Journal 24: 306; republished in Id. Aspects of Hobbes (Oxford: Clarendon Press, 2002), pp. 53-79.

${ }^{47}$ See Quentin Skinner, Visions of Politics (Cambridge, 2002), vol. III “Hobbes and Civil Science”, pp. 287-307.

${ }^{48}$ Hobbes, Leviathan, 1651: I, Ch. XX, p. 161.

${ }^{49}$ See Barbara Arneil, John Locke and America. The Defence of English Colonialism (Oxford: Oxford University Press, 1996).

${ }^{50}$ See Richard Tuck, The Rights of War and Peace. Political Thought and the International Order from Grotius to Kant (Oxford: Oxford University Press, 1999), pp. 109 ff.

${ }^{51}$ Hobbes, Leviathan, I, Ch. XXX, p. 273.

${ }^{52}$ Ibid., I, Ch. XV, p. 124.

${ }^{53}$ Hobbes, On the Citizen, I, Ch.III, § 16-17, pp. 50-51.

${ }^{54}$ Gregory S. Kavka, Hobbesian moral and political theory (Princeton N.J: Princeton University Press, 1986), pp. 210-224.

${ }^{55}$ Hobbes, On the Citizen, II, Ch.XIII, § 4, p. 143.

${ }^{56}$ See Francis Bacon, Essays or Counsels civil and moral, Ch. XV 'Of Seditions and Troubles', 1625. 
${ }^{57}$ On the debate on the English colonization of America in the latter half of the XVIIe century, see the defensors of the English plantations : Thomas Mun, England's Treasure by Forraign Trade, 1664 ; Sir Josiah Child, A New Discourse on Trade, 1689 ; Charles Davenant, Discourses on the Public Revenues and on the Trade of England, 1698.

${ }^{58}$ Hobbes, The Elements of Law, I, Ch. XVI, § 12, p. 87.

${ }^{59}$ Hobbes, Leviathan, I, Ch. XIII, p. 101.

${ }^{60}$ Ibid., I, Ch. XIV, p. 110.

${ }^{61}$ See Howard Warrender, The Political Philosophy of Hobbes. His theory of Obligation (Oxford: Clarendon Press, 1957), pp. 64-65; pp. 115 ff.

${ }^{62}$ Grotius, De Jure Belli ac Pacis, II, Ch. I, § 17, p. 108; translated by me.

${ }^{63}$ Hobbes, Leviathan, I, Ch. XIII, p. 100.

${ }^{64}$ Ibid., p. 100.

${ }^{65}$ Ibid., I, Ch. XIV, p. 110.

${ }^{66}$ Gentile, De Iure Bell Libri tres, I, Ch. XIII, p. 63.

${ }^{67}$ Hobbes, Leviathan, II, Ch. XXVII, p. 236.

${ }^{68}$ Ibid., I, Ch. XV, p. 126.

${ }^{69}$ Ibid., I, Ch. VI, p. 47.

${ }^{70}$ Ibid., I, Ch. XIII, p. 101.

${ }^{71}$ See V.G. Kiernan, The Duel in European History; Honour and the Reign of Aristocracy (Oxford: Oxford University Press, 1988), pp. 194-195.

${ }^{72}$ See Hobbes, Leviathan, I, Ch. X, pp. 70-80.

${ }^{73}$ Ibid., I, Ch. XIII, p. 100.

${ }^{74}$ Hobbes, The Elements of Law, II, Ch. IX, § 9, p. 184.

${ }^{75}$ Ibid. I underline.

${ }^{76}$ Coady, 'The peculiarity of Hobbes's concept of natural right', p. 178.

${ }^{77}$ Grotius, De Jure Belli ac Pacis, II, Ch.I, § 2, p. 102.

${ }^{78}$ Hobbes, On the Citizen, II, Ch. V, § 2, p. 69.

${ }^{79}$ Ibid., II, Ch. V, § 1, p. 69.

${ }^{80}$ Haggenmacher, Grotius et la doctrine de la guerre juste, p. 597. 
${ }^{81}$ See Luc Foisneau, Luc, "Leviathan's theory of Justice", in Sorell, Tom and Foisneau, Luc (ed.). Leviathan After 350 Years (Oxford: Clarendon Press, 2004), p. 105.

${ }^{82}$ Hobbes, Leviathan, I, Ch. XIV, p. 113.

${ }^{83}$ Ibid., pp. 113-114.

${ }^{84}$ See Leviathan., I, Ch. XV, end.

${ }^{85}$ Hobbes, On the Citizen, Ch. XIV, p. 156.

${ }^{86}$ Hobbes, Leviathan, I, Ch. XIV, p. 110.

${ }^{87}$ Ibid., I, Ch. XV, p. 115.

${ }^{88}$ Ibid., I, Ch. XIII, p. 103.

${ }^{89}$ Emmanuelle Jouannet, Emer de Vattel et l'émergence doctrinale du droit international classique (Paris: A. Pedone, 1998), pp. 24-25.

${ }^{90}$ Emerich de Vattel, The Laws of Nations or the Principles of natural law Applied to the Conduct and to the Affairs of Nations and of Sovereigns, translation of the edition of 1758, by Charles G. Fenwick (New York: William S. Hein and co., 1995), Vol. III, p. 4 a.

${ }^{91}$ Hobbes, On the Citizen, II, Ch. XIV, p. 156.

${ }^{92}$ Hobbes, Leviathan, II, Ch. XXX, p. 279.

${ }^{93}$ Ibid.

${ }^{94}$ In his earlier book, De Jure Praedae Commentarius where he distinguishes between a jus gentium primarium (identified with laws of nature) and a jus gentium secondarium (see Haggenmacher Grotius et la doctrine de la guerre juste, pp. 361-382).

${ }^{95}$ Grotius, De Jure Belli ac Pacis, I, I, § 14, pp. 6-7.

${ }^{96}$ Hobbes, Leviathan, I, Ch.XIII, p. 103.

${ }^{97}$ Hobbes, On the Citizen, I, Ch.III, § 27, p. 54.

${ }^{98}$ Ibid., II, Ch. V, § 2, p. 69.

${ }^{99}$ Thomas Hobbes, Elementorum Philosophice Sectio Tertia, De Cive. Thomas Hobbes Malmesburiensis Opera Philosophica Quae Latine Scripsit Omnia In Unum Corpus Nunc Primum Collecta (London: Scientia Verlag Aalen, John Bohn, 1839-1845, reimprinted Aalen, 1966), vol. II, p. 210.

100 See Hobbes's criticism of E. Coke and of the Common Law as a law derived from historical knowledge : Dialogues on the Common Law. 
${ }^{101}$ Richard Cox, Locke on War and Peace (Oxford: 1960), pp. 154 ff.

102 Hobbes, The Elements of Law, I, Ch. XIX, § 2, p. 100.

${ }^{103}$ Ibid.,p .101.

${ }^{104}$ Ibid., I, Ch. XVII, § 15, p. 95. Yet, Hobbes's insistence on 'honour' weakens itself in his following political treatises.

${ }^{105}$ Hobbes, Leviathan, I, Ch. XV, p. 126.

${ }^{106}$ I borrow this term from Donald W. Hanson, "Thomas Hobbes's "highway to peace"”, International Organization, 38, 2, Spring 1984: 352, but in another meaning than he.

${ }^{107}$ Hanson, "Thomas Hobbes’s "highway to peace"”, p. 353.

${ }^{108}$ Hobbes, The Elements of Law, II, Ch. 9, § 9, p. 184.

${ }^{109}$ Hobbes, On the Citizen, Preface, p. 15. 